\title{
Waste-to-Energy Potential Using Municipal Solid Waste as One Implementation of Jakarta Smart City
}

\author{
Muhammad Rayhan Syahida Ramadhan ${ }^{1}$, Muhammad Ikhsan ${ }^{2}$, Ridha Muhlita Putra ${ }^{3}$, \\ Joni Welman Simatupang ${ }^{4 *}$, Sealtial Mau ${ }^{5}$, Emil Robert Kaburuan ${ }^{6}$ \\ 1,2,3,4Electrical Engineering Study Program, President University, Cikarang 17530, Jawa Barat, Indonesia \\ ${ }^{5}$ Department of Mechanical Engineering Education, Faculty of Teacher Training and Education, Universitas Nusa \\ Cendana, Kupang 85001, East Nusa Tenggara, Indonesia \\ ${ }^{6}$ Information System Management Department, BINUS Graduate Master Program, Jakarta Barat 11480, Indonesia \\ *Koresponden email: joniwsmtp@ president.ac.id
}

Received: August 22, 2021

Accepted: October 15, 2021

\begin{abstract}
The background of this research is the escalation of DKI Jakarta's residence which lead to the other two impacting factors, the use of electricity that increase to 5.8\% in 2019 and the municipal waste escalation. The objective of this research is to find potential electrical energy that can be produced from waste-toenergy (WTE) technology of IWMS (Integrated Waste Management Site) Bantargebang (Bekasi), where most of the waste come from the people of DKI Jakarta. Furthermore, with the application of WTE, there is also a potential from the smart city implementation in DKI Jakarta. By using the mathematical model and secondary data gathering from the government of DKI Jakarta, we found that the potential of electrical energy that can be produced can reach $8.6 \mathrm{GWh} /$ day, which contributed up to $9 \%$ to from the energy distributed to DKI Jakarta. Moreover, by applying WTE, there is also a potential of implementing other indicators of smart city that has been propagated by the government of DKI Jakarta.

Keywords: Waste-to-Energy (WTE), Municipal Solid Waste (MSW), Smart City, DKI Jakarta, IWMS Bantargebang.

Abstrak

Masalah yang melatarbelakangi penelitian ini adalah peningkatan jumlah penduduk DKI Jakarta yang mengakibatkan peningkatan pada dua faktor lain, penggunaan listrik yang naik 5,8\% pada 2019 dan meningkatnya sampah yang dihasilkan. Tujuan dari penelitian ini adalah mencari potensi energi listrik yang dapat dibangkitkan dari teknologi WTE pada timbulan sampah yang terdapat di TPST (Tempat Pengolahan Sampah Terpadu) Bantargebang (Bekasi) yang merupakan muara dari semua sampah yang berasal dari DKI Jakarta. Lebih lanjut, dengan penerapan WTE, didapat pula potensi dari implementasi smart city di DKI Jakarta. Dengan menggunakan model matematika dan pengumpulan data sekunder dari portal pemerintah DKI Jakarta, didapat potensi energi listrik yang dapat dibangkitkan mencapai 8,6 GWh/hari yang merupakan 9\% kontribusi dari energi yang disalurkan ke DKI Jakarta. Terlebih, dengan mengaplikasikan WTE, terdapat pula potensi mengimplementasikan indikator-indikator dari smart city yang di canangkan oleh DKI Jakarta. Kata Kunci: Waste-to-Energy (WTE), Municipal Solid Waste (MSW), Smart City, DKI Jakarta, TPST Bantargebang.
\end{abstract}

\section{Introduction}

Indonesia is a South-East Asia Pacific country that sit in fourth rank according to the populationnumber [1]. Given statistic data from Badan Pusat Statistik (BPS) Indonesia, from the population census (SP) in September 2020, there's around 279.20 million people in Indonesia [2]. With this amount of population, the needs of electricity will be big too. Furthermore, with the rise of Indonesia's population, around 32.56 million people, from the last population census in 2010 , or is equal to 1.25 percent population growth rate, will affect the needs of electricity. In around $2018-2019$ the electricity costumer increases for around 3.7 million [3]. Furthermore, in 2019, Indonesia has distributed $247.6 \mathrm{GWh}$ electricity to around 75.7 million customers and is predicted to continue increasing by thefollowing years [3]. Thus, it's true that the increase of population will also increase the electricity needs.

DKI Jakarta is the busiest city in Indonesia. As the capital city of Republic Indonesia, Jakarta become the biggest metropolitan city in Indonesia, in fact that Jakarta placed in $6^{\text {th }}$ position the biggest metropolitan city in the world. How could not, with an area of about $662.33 \mathrm{~km}^{2}$ (sea: $6,977.5 \mathrm{~km}^{2}$ ) 
occupied by a population of 10 million or a population density of Jakarta reaching 15,663 people every $1 \mathrm{~km}^{2}$ in 2017 [4-5].

Furthermore, coupled with the increase of population, it can be confirmed that there's an increase of electricity demand in Jakarta recorded by Badan Pusat Statistik (BPS) Indonesia. Total electricity distribution to DKI Jakarta in 2018 is around 32,000 Giga Watt-hour (GWh) and has increased around 5.8 percent in 2019 approximately becoming 34,000 GWh, or 13.7 percent from the total distributed electricity in all over Indonesia [6]. But this huge electricity usage is not followed by an adequate electricity production, given by the data from BPS in 2019, the amount of electricity produced by DKI Jakarta only reached 13,000 GWh, 27,000 GWh less from the total electricity distributed to DKI Jakarta [7].

Other effects that took place as the result of population's escalation is the increase of Municipal Solid Waste (MSW) in Indonesia, especially in DKI Jakarta, that reached around 1.8 million tons. However, Sistem Informasi Pengelolaan Sampah (SIPS) stated that only around 83\% MSW in DKI Jakarta had been managed and processed [8]. Deeper, DKI Jakarta's MSW, over the years, has increased exponentially from year to year following the growth of population in Jakarta. To battle this problem, the government has applied some programs such as 3R (Reduce, Reuse, Recycle) and Waste-to-energy to tackle the electricity request of DKI Jakarta. Yet, outside of that, MSW management in Indonesia still relies heavily on landfill. Where $69 \%$ of total MSW went into the landfill and the others got independently handled [9]. One of the largest and widely used one by the Jakarta government is the Bantargebang Landfill in Bekasi (see Fig.1), based on Portal Statistik Sektoral Provinsi DKI Jakarta says that around 6.7 thousand tons waste in average enter Bantargebang landfill [10].

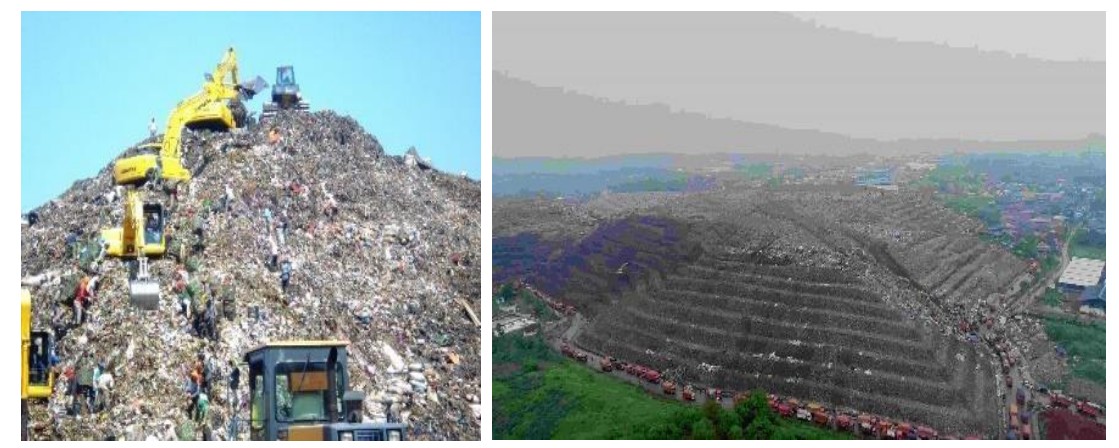

Figure 1. Bantargebang landfill pictures.

Source: Google

It is stated that, in TPST (Landfill) Bantargebang, from 2017 to 2019, the average trash's weight increased by $17.37 \%$ from 6561 Ton/day to 7702 Ton/day, where it consists of food waste (43\%), plastic (28\%), fabric (8\%), papers (5\%) and others as shown on Fig. 2 and Fig. 3 respectively [11]. This data will become this research concern for the fuel of the Waste-to-Energy (WTE) potency calculation further.

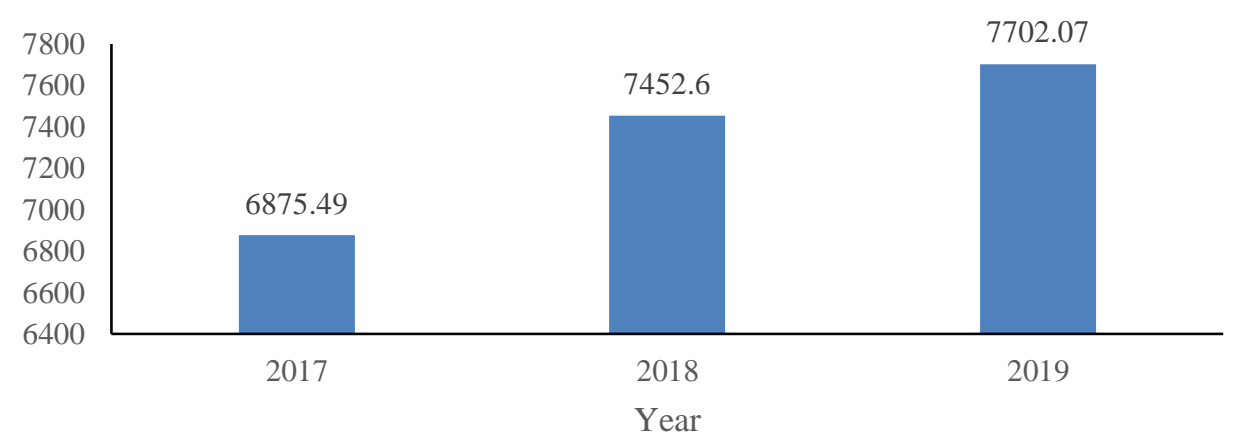

Figure 2. Total waste weight in TPST Bantargebang [11] 


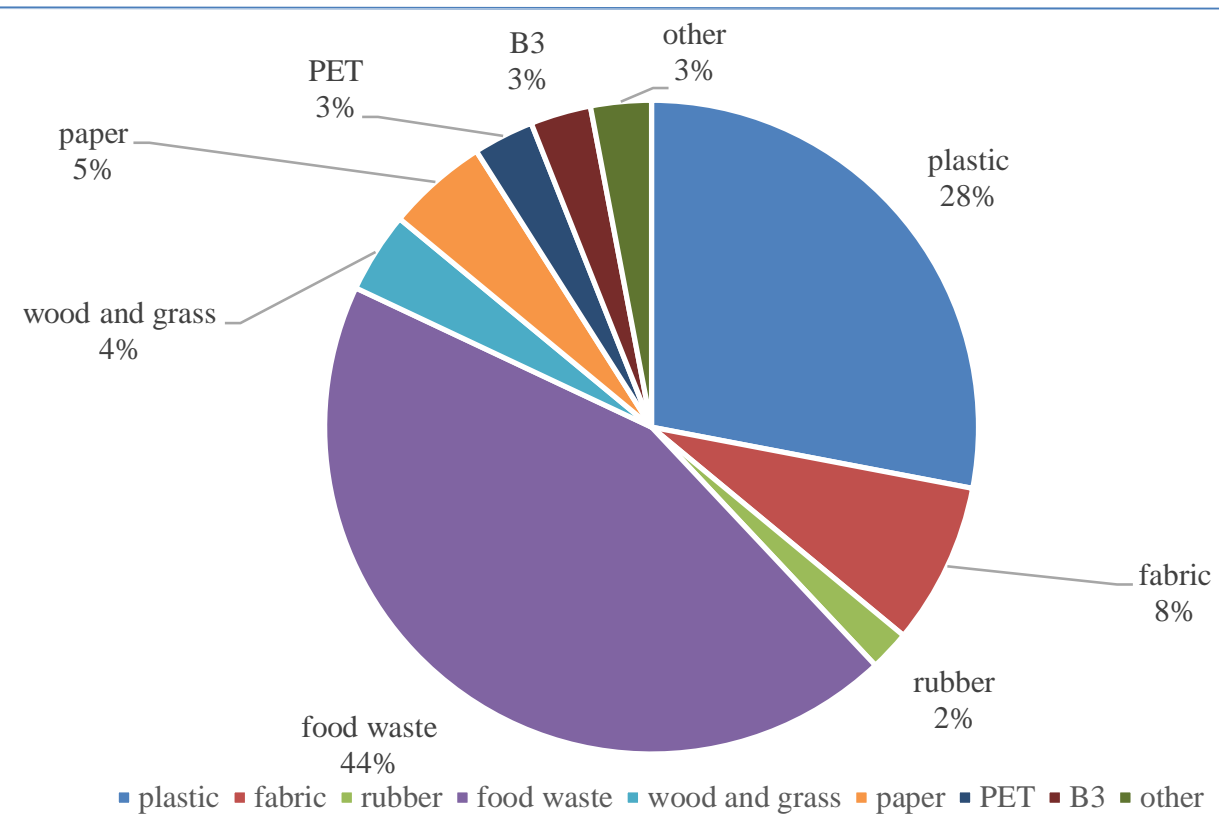

Figure 3. Waste composition in TPST Bantargebang [11]

A way to tackle both problems before is implementing the Waste-to-Energy (WTE) technology. WTE is an energy producing technology that takes advantage of MSW as the main fuel. Energy produced by WTE varies, there are synthetic gas, (bio) oil, steam, and heat. Furthermore, this technology is combined with a steam-powered electric generator to generate electricity [12].

There are two types technology commonly of WTE to produce electricity from the MSW. Frist one is the technology that use the thermal conversion. This technology works to produce energy from the MSW handling in the form of heat and, further, the heat will transfer to electricity with help of other engine and this technology also produce other chemical products [13-14]. This technology, thermal conversion, use the waste calorific value as the important parameter as the potency energy that can be extracted and with the low of moisture value (percentage water that contain in the waste) [15]. Several applications of this WTE technology are incineration, gasification, and pyrolysis. Incineration used to incarnate the waste in the range temperature between $850^{\circ}-1200^{\circ} \mathrm{C}$ and this heat will further used to heat the steam engine and produced the electricity $[16,17]$.

The greatest advantage of incineration is that all type of the waste, organic and inorganic, can become the fuel; thus, up to $80 \%$ volume of waste can be reduced; with low complexity of the plant, it can be applied in urban areas and fulfill technical and environmental regulations [13, 19-23]. Gasification and pyrolysis are similar in technology concept, used topartially burn the waste in the temperature range between $550^{\circ}-1600^{\circ} \mathrm{C}$ for gasification and $500^{\circ}-800^{\circ} \mathrm{C}$ for pyrolysis with lack of oxygen environment that produced gas (syngas) like $\mathrm{CO}, \mathrm{CO}_{2}, \mathrm{H}_{2} \mathrm{O}$, char, tar, hydrogen, bio-oil [1718]. These technologies have advantage in the smaller size plant compared to the incineration, thus it can be applied in the industrial and urban areas, and the process result, in the fact is syngas, can be used in different purposes. Besides, the drawback of these technologies is the net energy that can be recovered might be lower in case of high value of humidity in the waste and the complexity makes a bit extra time to implement it [13, 19-23].

The other type is the bioconversion technology that utilize the microorganism to decompose the waste in the form of solids, sludge, or gas. One of the products that commonly use in WTE is the methane gas $\left(\mathrm{CH}_{4}\right)$, that will be convert it to other energy in the form of compressed natural gas $(\mathrm{CNG})$. One application of this technology conversion is anaerobic digestion [13, 24]. In anaerobic digestion, the waste decomposed by the biological reagents in anaerobic (with no oxygen) environment [20]. The biggest challenge of this technology is the waste that can be used is just the organic one, thus waste sorting is necessary. Besides it, this technology process will avoid the green-house gases and produce product that rich of nutrients, it can be used as the fertilizer. Furthermore, the biogas product must be treated again before it can be used. Besides, the complexity of this technology is relatively low and usually apply in rural areas [13, 19-23]. 
Focusing on Indonesia, there are several studies that has been conducted to apply the waste-toenergy to prevent trash and others residual waste problem in several cities, like analysis research from Widyawidura in Yogyakarta [24]. Research conducted by Widyawidura by using MSW to be applied in WTE with 1 MW target in Yogyakarta in 2014, with the waste composition data at Yogyakarta from 2009 that is gathered in all TPSA (final landfill) in Yogyakarta. From their research, with classifying the waste as the organic, that will be treated with anaerobic digestion, and inorganic, that will be treated with gasification, had electrical energy up to $1541,97 \mathrm{~kW}$. However, their research used the lower calorific value (LCV) with a constant value and not detailed with each composition. Thus, this research updates more detail potency calculation with data of LCV, and also used DKI Jakarta as the area because the MSW in Jakarta has more potential compared to Yogyakarta and also can decrease the waste in DKI Jakarta [24].

DKI Jakarta is a city that has become a pioneer on the concept of smart city in Indonesia. This is stated in the DKI Jakarta Governor Regulations no. 280, 2014 about organization and work procedures of the Jakarta Smart City management unit that had been planned in RPJMD 2013 - 2017. Smart city described as a city that can use all of life aspect with the help of technology in systematic and efficient ways so it will improve the people life [25]. With the smart city implementation, there must be several fans to follow, that are: smart living, related to quality of life; smart mobility, related to the ease of transportation; smart governance, related to the governor policy; smart economy, related to the economy states and financial prosperity; smart environment, related to the environment sustainability and renewable energy; and smart people, related to the human resource as seen in Fig. 4 [26]. One indicator from smart city is smart environment, that related to the sustainability of the environment and the use of renewable energy [26]. Thus, with the WTE implementation could become a way towards Jakarta smart city.

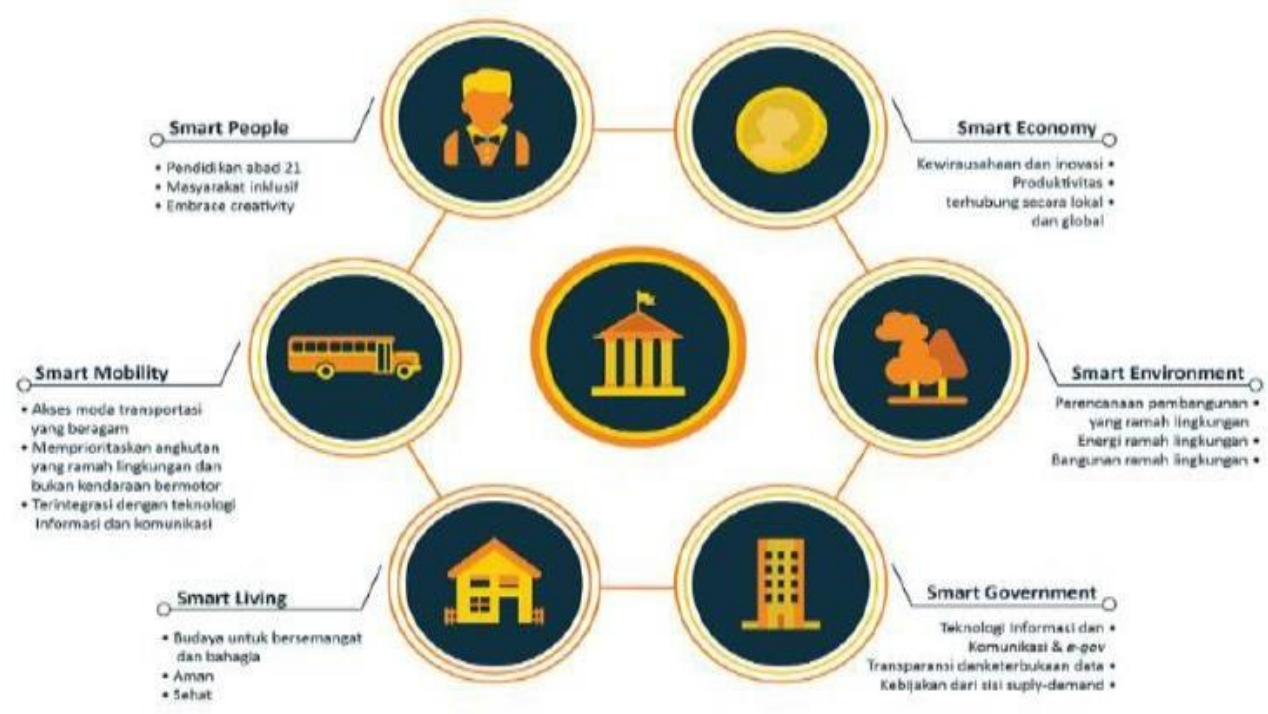

Figure 4. Smart City wheel framework [26]

Furthermore, this paper intends to analyze WTE potency that can be produced on DKI Jakarta, especially in TPST Bantargebang (landfill), as the case study and use mathematical model approach in given data around 2017 - 2019. Hence, it will obtain the data of electrical energy that can be raised with several kinds of WTE technology. Furthermore, this research is also become an insight of one way to implement the Jakarta smart city indicator, smart environment, that had been held by the DKI Jakarta government.

\section{Methodology}

This research used the study literature method from several researches about the potency and application of WTE that had conducted with several case studies. Furthermore, this research uses the combination of quantitative approach, in the energy potency from WTE calculation, and comparative, in comparing the data of the needs of electricity and the result of the potential energy that made; also give the connection with the DKI Jakarta smart city concept. Data that used is the secondary data 
gathered from the environmental services of DKI Jakarta's portal in the period between $2017-2019$ and used the TPST Bantargebang as the place of the case study. The choice of use TPST Bantargebang related to the data that stated biggest part of MSW landfilling in DKI Jakarta [10].

WTE technology used in this research is consisted of incineration and gasification for the thermalconversion, and anaerobic digestion as used the bioconversion method. This research conduct in three analyses: first analysis is to find the electric energy potency of all WTE technology based on DKI Jakarta MSW situation; second analysis is electric energy potency of the combination incineration and anaerobic digestion WTE; and third analysis is to find the electric energy potency of the combination of gasification and anaerobic digestion WTE. The reason of combining thermal conversion with the bioconversion is to fulfill the waste that cannot processed by thermal by using the bioconversion, and vice versa. Furthermore, from those analysis, this research will try to link WTE applied with the implementation of DKI Jakarta smart city concept.

For the calculation, to find the electric energy potency gathered from WTE, this research used mathematical models that had been conducted before by several researches, it is intended to adjust this research calculation with the mathematical calculation that had modeled and proved to find the electric potency. Thus, mathematical model for WTE with thermal conversion, with energy conversion efficiency $18 \%$ for incineration [27] and 25\% (gas turbine) for gasification [15]. Hence equation (1) and (2) obtained as:

$$
\begin{aligned}
E R P_{t} & =L C V * W / 860 \\
P_{t} & =E R P_{t} * \eta_{E C}
\end{aligned}
$$

where,

$E R P_{t} \quad$ Energy recovery potential, raw energy gathered from the waste for thermalconversion (MWh/day)

LCV Lower Calorific Value of the waste, depends on what kind of waste $(\mathrm{kcal} / \mathrm{kg})$

W Total weight of the waste (ton/day)

$\frac{1}{860} \quad$ Constant for converting kcal to $\mathrm{kWh}$

$P_{t} \quad$ Electric power potential from the WTE with thermal conversion (MWh/day)

$\eta_{E C} \quad$ Energy conversion efficiency $(\%)$

Whereas, for WTE in this research use bioconversion, anaerobic digestion, with energy conversion efficiency $25 \%$ (gas turbine) [15]. Hence equation (3) and (4) obtained as:

$$
\begin{gathered}
E R P_{t}=L C V_{\text {methane }} * V S * O B F * D E * \frac{w}{\mu_{\text {methane }} * 860} \\
P_{b}=E R P_{b} * \eta_{E C}
\end{gathered}
$$

Where,

$\begin{array}{ll}E R P b & \begin{array}{l}\text { Energy recovery potential, raw energy gathered from the waste with bioconversion } \\ (\mathrm{MWh} / \text { day })\end{array} \\ L C \mathrm{~V}_{\text {methane }} & \begin{array}{l}\text { Lower Calorific Value of the methane, } 4475 \mathrm{kcal} / \mathrm{m}^{3}[28] \\ W\end{array} \\ \text { Total weight of the waste (ton/day) } \\ V S & \text { Volatile solid, will depend on the waste (\%) } \\ O B F & \text { Organic biodegradable fraction, around } 66 \%[29] \\ & \end{array}$




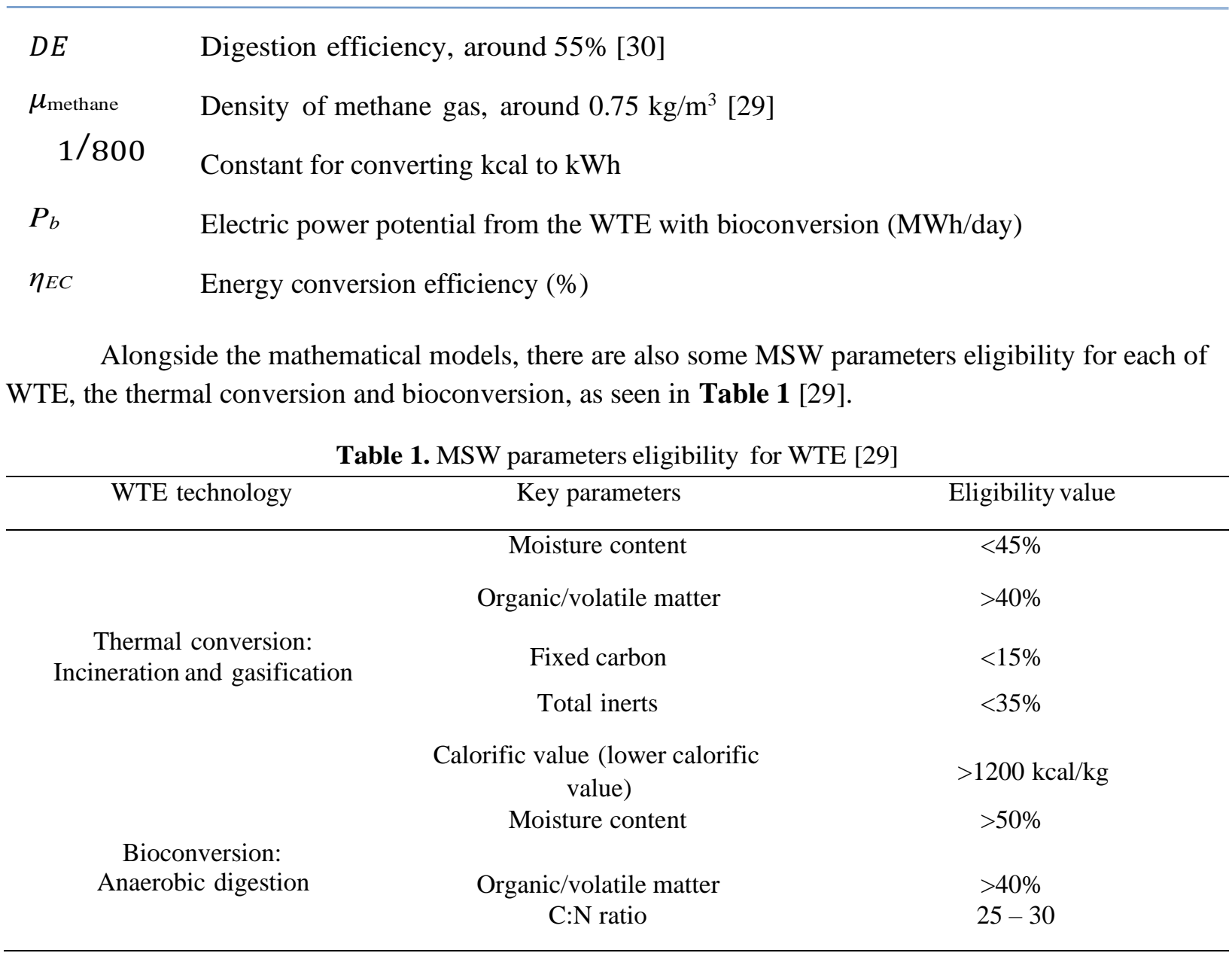

\section{Results and Discussion}

Before discussing the mathematical calculation model further, there are differences in characteristic ofthe MSW depending on the place it is in, especially at Indonesia, where it is a tropical country. Therefore, there is a need to discern the characteristics of waste that can represent Indonesia's waste-type. The data Obtained from the research of Characteristic of waste in Indonesia from Novita and Damanhuri are shown in Table 2 [31].

Table 2. MSW characteristics in Indonesia [31]

\begin{tabular}{lcccc}
\hline & Moisture content $(\%)$ & Volatile solid $(\%)$ & $\begin{array}{c}\text { Fixed carbon } \\
(\%)\end{array}$ & LCV (kcal/kg) \\
\hline Plastic & 1 & 92 & 2 & 10382,32 \\
Fabric & 7 & 95 & 0.5 & 4010,65 \\
Rubber & 2 & 51 & 14 & 5106,45 \\
Food waste & 72 & 78 & 4 & 1437.86 \\
Wood and grass & 79 & 59 & 30 & 906,08 \\
Paper & 5 & 72 & 8 & 2884.84 \\
PET & 4 & 99 & 0.25 & 5252,42 \\
\hline
\end{tabular}

The result will be explained in accordance with the methods in section 2, there will be three analyses: First, to find out the potential from every WTE technology corresponding to data obtained: Second, to find the energy that can be produced potentially if we combined incineration with anaerobic digestion, its advantages and disadvantages, and also its potential contribution to the electricity needs in DKI Jakarta: Third, same with the second analysis, the difference is the WTE technologies used are gasification and Anaerobic digestion. By Using the mathematical model from equation (1) and (2) for 
thermal conversion and equation (3) and (4) for bio conversion, while also considering the parameter of MSW's eligibility on table (3), will resulted on the analysis result as follows.

First Analysis: Electric Energy Potency from Each WTE Technologies

The total combination of waste amount from 2017-2019 period with the average waste composition obtained from Portal TPST Bantargebang [11], we get the total amount of waste per composition from that period just like as it shown on Table 3.

Table 3. Total weight from each kind of waste [11]

\begin{tabular}{ccccc}
\hline \multirow{2}{*}{ Waste composition } & $\begin{array}{c}\text { Percentage } \\
(\%)\end{array}$ & 2017 & 2018 & 2019 \\
\cline { 3 - 4 } & 28 & 1925.1372 & 2086.728 & 2156.5796 \\
Plastic & 8 & 550.0392 & 596.208 & 616.1656 \\
Fabric & 2 & 137.5098 & 149.052 & 154.0414 \\
Rubber & 44 & 3025.2156 & 3279.144 & 3388.9108 \\
Food Waste & 4 & 275.0196 & 298.104 & 308.0828 \\
Wood and & & & 372.63 & 385.1035 \\
Grass & 5 & 343.7745 & 223.578 & 231.0621 \\
Paper & 3 & 206.2647 & 223.578 & 231.0621 \\
PET & 3 & 206.2647 & 223.578 & 231.0621 \\
B3 & 3 & 206.2647 & 7452.6 & 7702.07 \\
Others & 100 & 6875.49 & & \multicolumn{2}{c}{ Total weight from each kind of waste (ton/day) } \\
\hline Total & & &
\end{tabular}

The B3-type waste does not constitute as an MSW or never been used as a biomass fuel for WTE, we will ignore that type of waste. We will also ignore the 'others' type of waste becausethere's no specific detail on what kind of waste it is so we can't categorize what kind of LCV that we will use. Ergo, there's only 7 types of MSW that will be used as a variable on this research's calculation, which is: Plastic, fabric, food waste, wood and grass, paper, and PET.

\section{Incineration}

The type of waste that fulfill the parameter that is used on the thermal conversion process according to table 3 and 4 are: Plastic, fabric, rubber, paper and PET. Referring to the equation (1) and (2) with the energy conversion efficiency used is 18\% [27] we get the potential electric energy in period $2017-2019$ as can be seen in Table 4.

Table 4. Total electric energy potency raised from incineration WTE

\begin{tabular}{cccc}
\hline \multirow{2}{*}{ Waste composition } & \multicolumn{3}{c}{ Total electric energy potency raised from incineration (MWh/day) } \\
\cline { 2 - 4 } & 2017 & 2018 & 2019 \\
\hline Plastic & 4183.407 & 4534.551 & 4686.342 \\
Fabric & 461.724 & 500.48 & 517.233 \\
Rubber & 146.969 & 159.306 & 164.638 \\
Paper & 207.572 & 224.995 & 232.527 \\
PET & 226.756 & 245.789 & 254.017 \\
\hline Total & 5226.428 & 5665.121 & 5854.757 \\
\hline
\end{tabular}

Source: Data analysis

The mathematical calculation model for electrical energy potential from incineration method, we obtained the result such as shown on table 4 . The total potential energy that is produced reaches $>5000 \mathrm{MWh} /$ day, it even reaches $5.8 \mathrm{GWh} /$ day. The biggest contribution came from plastic waste, which is the waste with the largest amount on TPST Bantargebang, seconded by fabric and other type of wastes. But there is a noteworthy detail from the rubber-type of waste. Rubber has a $14 \%$ fixed carbon 
on its material. Almost hitting 15\% which is one of the parameters for MSW eligibility parameter to be used on WTE.

\section{Gasification}

Differed from incineration method, gasification is done by low oxygen environment partial heating which will produce gas products and bio-oil [17-18]. While it has a different type of combustion done to the process, the energy conversion method still uses the same method as incineration which is thermal conversion. Ergo, to find the potential electricity energy from the gasification prosses, we still can use equation (1) and (2) using gas turbine for the energy conversion that has an efficiency of approximately $25 \%$ [15]. Wastes that can be used as a fuel is the same with incineration. From the mathematical calculation model based on waste heap and its classification from 2017-2019 period [11], we get the energy potential result is shown on Table 5.

Table 5. Total electric energy potency raised from gasification WTE

\begin{tabular}{cccc}
\hline \multirow{2}{*}{ Waste composition } & \multicolumn{3}{c}{ Total electric energy potency raised from gasification $(\mathrm{MWh} /$ day $)$} \\
\cline { 2 - 4 } & 2017 & 2018 & 2019 \\
\hline Plastic & 5810.288 & 6297.988 & 6508.808 \\
Fabric & 641.283 & 695.111 & 718.379 \\
Rubber & 204.124 & 221.258 & 228.664 \\
Paper & 288.295 & 312.494 & 322.954 \\
PET & 314.939 & 341.374 & 352.801 \\
\hline Total & 7258.929 & 7868.224 & 8131.606 \\
\hline
\end{tabular}

Source: Data analysis

The total electric potential energy produced by the gasification technology reached 8.1 $\mathrm{GWh}$ /day or about $2.2 \mathrm{GWh} /$ day more than compared to the incineration method. But the results is depended on the efficiency on the energy conversion tool, as Barz explained, gas turbine has a $25 \%$ efficiency on the plant demonstration, 7\% higher than what Grupo EPM used on his research. But, on Barz research, is noted that the energy conversion technology that used steam has an efficiency up to $30 \%[15,27]$. Incineration and gasification have a different type of output. Incineration only produces heat, while gasification produces gas and bio-oil that can be used outside of electrical energy.

Anaerobic Digestion

Anaerobic Digestion, AD for short, is one of WTE technology that uses a bioconversion to convert waste to biogas, especially methane gas $(\mathrm{CH} 4)$ that could be converted to other energy in a form of compressed natural gas $(\mathrm{CNG})$. AD will use an organic waste that has a considerably high-water content. So, from the data that we take from TPST Bantargebang, there are a few wastes that can be used for this process, namely: Food waste, wood, and grass. From the mathematical model (3) and (4), and with the waste data from 2017-2019 in TPST Bantargebang [11], we get the following data that shown in Table 6.

Table 6. Total electric energy potency raised from anaerobic digestion WTE

\begin{tabular}{cccc}
\hline \multirow{2}{*}{ Waste composition } & \multicolumn{4}{c}{ Total electric energy potency raised from anaerobic digestion (MWh/day) } \\
\cline { 2 - 4 } & 2017 & 2018 & 2019 \\
\hline Food waste & 477.369 & 517.438 & 534.759 \\
Wood and grass & 20.686 & 22.422 & 23.173 \\
\hline Total & 498.055 & 539.86 & 557.932 \\
\hline \multicolumn{2}{c}{ Source: Data analysis }
\end{tabular}

We can see that AD cannot be compared to incineration and gasification. If we look at the electrical energy potential produced, it can only give a maximum of $557 \mathrm{MWh} /$ day, with many biological factors in effect. one of the proofs can be observed from the mathematical model, just like 
$\overline{\mathrm{OBF}}$ and $\mathrm{DE}$, there's a lot of energy loss from the process. And AD or more commonly, WTE technology, uses bioconversion, where it can only process organic waste. But, beside the energy produced, bioconversion has an output product of gasses and can be utilized as an electrical energy, especially when the process of waste decomposing is occurring. AD does not produce greenhouse gasses so it is eco-friendly.

\section{Second Analysis: Electric Energy Potency of The Combination Incineration and Anaerobic Digestion}

To perform the waste process for either organic or inorganic waste, there are specific steps that we have to take to utilize WTE technology fully. This is because thermal conversion is not efficient enough in processing wastes that has a high-water content and bioconversion cannot process inorganic wastes. One of the ways to make it possible to process every type of waste is to combine WTE with thermal conversion and WTE with bioconversion. Besides the ability to process the two types of waste, the combination between these two WTE's could produce a variation from the produced product so that it can be utilized on other application. By combining incineration as a thermal conversion technology with anaerobic digestion as a bioconversion technology, we can get the total potential energy from the total combination of Table 4 and Table 6 so that we can get the data at Table 7.

Table 7. Total electric energy potency from combination of incineration and anaerobic digestion

\begin{tabular}{cccc}
\hline \multirow{2}{*}{ WTE technology } & \multicolumn{3}{c}{ Total electric energy potency raised (MWh/day) } \\
\cline { 2 - 4 } & 2017 & 2018 & 2019 \\
\hline Incineration & 5226.428 & 5665.121 & 5854.757 \\
Anaerobic digestion & 498.055 & 539.86 & 557.932 \\
\hline Total & 5724.483 & 6204.981 & 6412.689 \\
\hline
\end{tabular}

Source: Data analysis

The potential energy that can be produced reaches $6.4 \mathrm{GWh} /$ day. There are some strengths and weaknesses from applying incineration and anaerobic digestion in DKI Jakarta, specifically at TPST Bantargebang. First, using incineration can process both of organic and inorganic waste, but that can be its own drawback when using organic waste where most of it has a high level of water content, like grass and food waste, where this can be handled by using anaerobic digestion; second, incineration plant and anaerobic digestion has a relatively low complexity to it, where it will be suitable at TPST Bantargebang, which is in Bekasi where it has dense population, but has an additional gas processing plant to process anaerobic plant, especially methane.

Third analysis: electric energy potency of the combination gasification and anaerobic digestion

Third analysis of this research will discuss other combination with the same goal, to search how much electrical energy potential can be produced by combining gasification and anaerobic digestion, and to find the strengths and weaknesses from said combination when applied to TPST Bantargebang. By referring to Table 5 for gasification and Table 6 for anaerobic digestion, the total electrical energy potential that can be produced is as follows shown in Table 8.

Table 8. Total electric energy potency from combination of gasification and anaerobic digestion

\begin{tabular}{cccc}
\hline \multirow{2}{*}{ WTE technology } & \multicolumn{3}{c}{ Total electric energy potency raised (MWh/day) } \\
\cline { 2 - 4 } & 2017 & 2018 & 2019 \\
\hline Gasification & 7258.929 & 7868.224 & 8131.606 \\
Anaerobic digestion & 498.055 & 539.86 & 557.932 \\
\hline Total & 7756.984 & 8408.085 & 8689.538 \\
\hline
\end{tabular}

Source: Data analysis

Table 8 shows the total electrical energy potential that can be produced by combining gasification and anaerobic digestion. The highest total potential energy that can produced is in the year 2019 with the total electrical energy potential of $8.6 \mathrm{GWh} /$ day. There is a difference in potential as much as $2.2 \mathrm{GWh} /$ day by using the incineration and anaerobic combination if compared with the second analysis. On the other, hand gasification is not will be better than incineration or vice versa. Because this research 
is using a mathematical model that has been applied before. This combination has its strengths and weaknesses to apply on TPST Bantargebang. First, by applying gasification and anaerobic digestion, both of these technologies have an output type of gas, because of that, the processing model of the output from both can be equalized with each other. Therefore, it can save planning cost; Second, with an output in the form of gas and synthetic gas, there is another element that can be utilized into another form of energy other than electrical energy, combined with the substances that we can get from anaerobic digestion and it can make a fertilizer; but with the high complexity of applying gasification plant, it will make its own challenges to apply it at TPST Bantargebang. So, with the relatively smaller plant size compared with incineration, gasification is also suitable to be applied in Bantargebang.

Three analysis that has been explained before, the electrical energy potential from each WTE is obtained. In the first analysis and with some WTE combination at the second and third analysis. For the first analysis, by comparing the electrical energy distributed in DKI Jakarta on the 2017-2019 period that is shown in Fig. 5 [3], we get the electrical energy potential contribution percentage from all three WTE that is able to be distributed on Table 9.

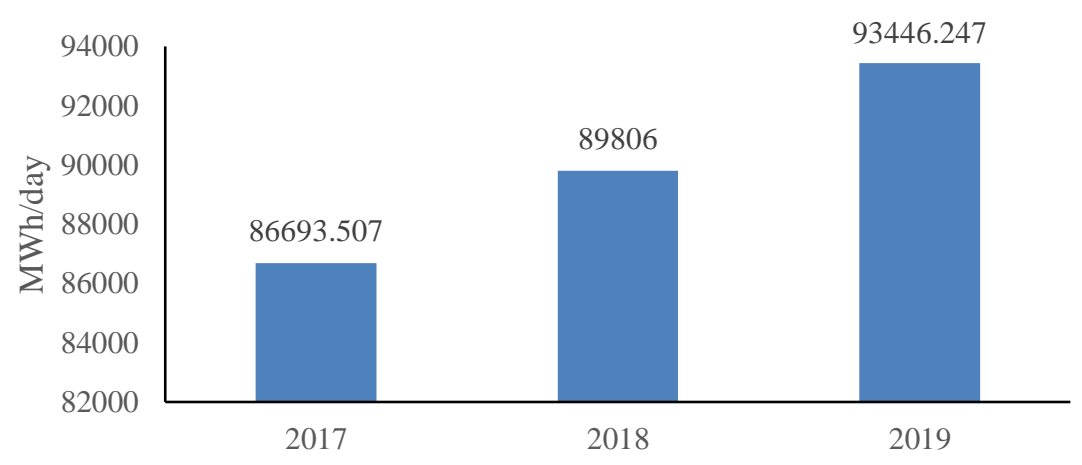

Figure 5. Total distributed electricity in DKI Jakarta 2017 - 2019

Table 9. Electric energy potential each WTE contribution to the demand electricity in DKI Jakarta

\begin{tabular}{cccc}
\hline \multirow{2}{*}{ WTE technologies } & \multicolumn{3}{c}{ Potential contribution percentage (\%) } \\
\cline { 2 - 4 } & 2017 & 2018 & 2019 \\
\hline Incineration & 6.03 & 6.31 & 6.27 \\
Gasification & 8.37 & 8.76 & 8.7 \\
Anaerobic digestion & 0.57 & 0.6 & 0.6 \\
\hline
\end{tabular}

WTE potential electrical distribution contribution can reach $8.7 \%$ using gasification when compared to electricity demand in DKI Jakarta. We got the contribution percentage to distributed electrical energy in DKI Jakarta on the second and third analysis as shown in Table $\mathbf{1 0 .}$

Table 10. Electric energy potential of the combination scheme to the demand electricity in DKI Jakarta

\begin{tabular}{cccc}
\hline \multirow{2}{*}{ Combination scheme } & \multicolumn{2}{l}{ Potential contribution percentage (\%) } \\
\cline { 2 - 4 } & 2017 & 2018 & 2019 \\
\hline $\begin{array}{c}\text { Incineration and Anaerobic } \\
\text { Digestion }\end{array}$ & 6.6 & 6.91 & 6.86 \\
$\begin{array}{c}\text { Gasification and Anaerobic } \\
\text { Digestion }\end{array}$ & 8.95 & 9.36 & 9.3 \\
\hline
\end{tabular}

In Table 10, using the combination of gasification and anaerobic digestion, the potential contribution can reach $9,3 \%$ or almost $10 \%$ of total electricity that has been distributed to across DKI Jakarta which is known for high electricity usage, while with incineration and anaerobic digestion the contribution almost reached 7\%. The concept of smart energy is focused on sustainable renewable energy, promoting an eco- friendly source of energy to provide electricity to the population. WTE system is one of the prime choices for this concept since it reduces MSW while also providing electricity to the population. 
Jakarta is facing a problem where wastes is not being organized, low frequency of waste transportation for the lower middle class, scarcity of TPS, according to [32], that there is still approximately $2.5 \%$ of total waste that has not been delivered to TPST in Jakarta. To have a Smart city, smart and clean environment is important to own. Furthermore, how scarce landfills are and how far one from each other, there is a need for more landfill near the middle-lower income community so that the time between dump truck session will be decreased, making the community cleaner.

There is also a demand to raise the people awareness to sort of organic to anorganic wastes. The coincide of demand to add separated garbage bin for each type of waste so that the organizing waste will be easier. With the waste organized, the WTE implementation for smart environment, the converted wastes to energy sources and then electrical energy. According to [33], $\mathrm{CO}_{2}$ emission from WTE plant, by using the anaerobic digestion method, reaches $357 \mathrm{Gco} 2$-eq $/ \mathrm{kWh}$ which is far lower than natural gas which is $500 \mathrm{Gco} 2-\mathrm{eq} / \mathrm{kwh}$ and Coal which reaches $+/-960 \mathrm{Gco} 2-\mathrm{eq} / \mathrm{kWh}$. This result shows that electricity production using MSW and WTE can decrease $\mathrm{CO}_{2}$ emission as much as 31.6711 tons $\mathrm{CO}_{2}-\mathrm{EQ} / \mathrm{kWh}$.

So, by implementing WTE, several smart city indicators will be implemented, such as smart people and smart government. The government is expected to give more consideration towards the aspects of waste management, environmental cleanliness. On the other hand, government instruction to educate and direct the society as a whole to make them more aware of how important waste separation, so that, in the future, it could be utilized for WTE application. Besides that, the application of WTE also has an effect to smart environment indicator, whereby using WTE. Waste can be transformed into a type of energy that can also be transformed into electrical energy, and because of that it will decrease the amount of waste in the environment. The last indicator that can be realized is smart mobility, where in this context DKI Jakarta demanded to make a more efficient waste transport management.

\section{Conclusion}

The objective of this research is to find the electrical energy potential that can be produced from WTE technology by employing some equations as the tools to calculate them. We found out that the potential energy from the WTE reaches $8 \mathrm{GWh}$ /day for the thermal conversion technology and reaches $0.55 \mathrm{GWh} /$ day for the bioconversion technology. So, by combining both of them, the potential energy that it can reach from combining gasification and anaerobic digestion is $8.6 \mathrm{GWh} /$ day. Moreover, by comparing the electricity produced and distributed in DKI Jakarta, we can know that the contribution reaches $9 \%$ in providing electrical energy. So, with just utilizing the wastes that is in TPST Bantargebang, WTE can contribute as much as 9\% electrical energy to DKI Jakarta that is well known as the biggest metropolitan city in Indonesia. Besides electrical energy contribution, WTE also has a role in the development of Jakarta smart city. This can be observed by looking at several aspects, like the waste management, waste transport and others that can be applicated to the indicators of smart city, just like smart people, smart government, smart environment and smart mobility.

\section{Acknowledgment}

The authors are grateful to Ms. Disa Evawani Lestari, English Faculty of President University for proof-reading this manuscript, and to Research Institute and Community Service (RICS) of President University for the support in publication.

\section{References}

[1] Worldometer, "Countries in The World by Population (2021)", 2021.

Internet: https://www.worldometers.info/world-population/population-by-country/. [March, 29th 2021]

[2] Badan Pusat Statistik, "Hasil Sensus Penduduk 2020”, 2020.

Internet: https://www.bps.go.id/pressrelease/2021/01/21/1854/hasil-sensus-penduduk-

2020.html. [March, 29th 2021]

[3] Badan Pusat Statistik, "Electricity Statistic 2014-2019”, 2020.

Internet:

https://www.bps.go.id/publication/download.html?nrbvfeve=MTU2MDAyZjRiOGI0

$\mathrm{NjBlZjk0M}$

WZhOTg1\&xzmn=aHR0cHM6Ly93d3cuYnBzLmdvLmlkL3B1YmxpY2F0aW9uLzIwMj 


\section{AvMTI}

vMjEvMTU2MDAyZjRiOGI0NjBlZjk0MWZhOTg1L3N0YXRpc3Rpay1saXN0cmlrLTI wMTQt

MjAxOS5odG1s\&twoadfnoarfeauf=MjAyMS0wMy0yOSAyMTowMjo0OQ\%3D\%3D.

[March, 29th 2021]

[4] Jakarta Tourism, "City of Jakarta Geographic and Climate", 2017.

Internet: http://jakarta-tourism.go.id/visit/blog/2017/06/city-of-jakarta-geographicand-climate. [April, 22nd 2021]

[5] Badan Pusat Statistik, "DKI Jakarta Dalam Angka“, 2019.

[6] Badan Pusat Statistik, "Listrik yang Didistribusikan Menurut Provinsi GigaWatthour (GWh),2017-2019", 2020.

Internet: https://www.bps.go.id/indicator/7/859/1/listrik-yang-didistribusikan-menurutprovinsi- gwh-.html. [March, $8^{\text {th }}$ 2021]

[7] Badan Pusat Statistik, "Listrik yang Dibangkitkan Menurut Provinsi (GWh), 20172019”, 2020. Internet: https://www.bps.go.id/indicator/7/859/1/listrik-yangdidistribusikan-menurut-provinsi- $\mathrm{gwh}$-html. [March, $8^{\text {th }}$ 2021]

[8] Sistem Informasi Pengelolaan Sampah Nasional, 2019. Internet: http://sipsn.menlhk.go.id/sipsn/

[9] Farizal F, Aji R, Rachman A, Nasruddin N, Indra Mahlia TM. Indonesia's Municipal Solid Waste 3R and Waste to Energy Programs. Makara Journal of Technology. 2017;21(3):8.

[10] Portal Statistik Sektoral Provinsi DKI Jakarta, "Rata-rata Jumlah Sampah yang Masuk keTempat Pembuangan Sampah Terakhir (TPST) Bantargebang, 2019”.

Internet: https://statistik.jakarta.go.id/rata-rata-jumlah-sampah-yang-masuk-ketempat- pembuangan-sampah-terakhir-tpst-bantar-gebang-2019/. [22 April 2021]

[11] Portal Resmi Unit Pengelola Sampah Terpadu Dinas Lingkungan Hidup Provinsi DKI Jakarta, "TPST Bantargebang." Internet: http://upst.dlh.jakarta.go.id/tpst/data. [19 April 2021]

[12] Campos U, Zamenian H, Koo DD, Goodman DW. Waste-to-Energy (WTE) technology applications for Municipal Solid Waste (MSW) treatment in the urban environment. Int. J. Emerg.Technol. Adv. Eng. 2015;5(2):504-8.

[13] S. Álzate Arias, B. Restrepo-Cuestas, y Á. Jaramillo-Duque, "Electricity generation potential from solid waste in three Colombian municipalities". TecnoLógicas, vol. 21, no. 42, pp. 111$128,2018$.

[14] Environment and Plastics Industry Council (EPIC), "A Review of the Options for the Thermal Treatment of Plastics," Mississauga, Ontario, 2004.

[15] Barz M. Biomass Technology for Electricity Generation in Community. Journal of Renewable Energy and Smart Grid Technology. 2008;3(1):1-0.

[16] Jain P, Handa K, Paul A. Studies on Waste-to-Energy Technologies in India \& a detailed study of Waste-to-Energy Plants in Delhi. International journal of advanced research. 2014;2(1):109-16.

[17] Arena U. Process and technological aspects of municipal solid waste gasification. A review. Waste management. 2012 Apr 1;32(4):625-39.

[18] Irena IR. Renewable energy technologies: Cost analysis series. Concentrating solar power. 2012;4(5).

[19] M. Chakraborty, C. Sharma, J. Pandey, and P. K. Gupta, "Assessment of energy generation potentials of MSW in Delhi under different technological options," Energy Convers. Manag., vol.75, pp. 249-255, Nov. 2013.

[20] O. K. M. Ouda, S. A. Raza, A. S. Nizami, M. Rehan, R. Al-Waked, and N. E. Korres, "Waste to energy potential: A case study of Saudi Arabia," Renew. Sustain. Energy Rev., vol. 61, pp. 328-340, Aug. 2016.

[21] X. Zhao, G. Jiang, A. Li, and L. Wang, "Economic analysis of waste-to-energy industry in China," Waste Manag., vol. 48, pp. 604-618, Feb. 2016. 
[22] K. A. Kalyani and K. K. Pandey, "Waste to energy status in India: A short review," Renew. Sustain. Energy Rev., vol. 31, pp. 113-120, Mar. 2014.

[23] G. V Ramakrishna, "Electricity Generation from Municipal Solid Waste," 2004.

[24] Widyawidura W, Pongoh JI. Potensi waste to energy sampah perkotaan untuk kapasitas pembangkit 1 MW di Propinsi DIY. Jurnal Mekanika Dan Sistem Termal. 2016 Apr 8;1(1):215.

[25] Widyaningsih D. Kota Surabaya Menuju Smart City (Doctoral dissertation, Universitas Gadjah Mada). 2013.

[26] Astutik EP, Gunartin G. Analisis Kota Jakarta Sebagai Smart City Dan Penggunaan Teknologi Informasi dan Komunikasi Menuju Masyarakat Madani. Inovasi. 2019 Dec 4;6(2):41-58.

[27] Grupo EPM, "Gestión y valorización de residuos sólidos urbanos (RSU). Evaluación de nuevas oportunidades de negocio," in 1aConferencia panamericana - Waste to Energy 2016, 2016, p. 25.

[28] Aydi A. Energy recovery from a municipal solid waste (MSW) landfill gas: A tunisian case study. Hydrol Current Res. 2012;3(4):1-3.

[29] Johri R, Rajeshwari VK, Mullick AN. Wealth from Waste: Trends and Technologies (3 $3^{\text {rd ed). }}$ 2011.

[30] MNES. "Green Energy from Wastes: Biomethanation Projects for Urban and Industrial Wastes Set Up under UNDP/GEF assisted Project on Development of High Rate Biomethanationfres as means of Reducing Greenhouse Gases Emission”. 2006. New Delhi: Ministry of Non - Conventional Energy Sources.

[31] Novita DM, Damanhuri E. Perhitungan Nilai Kalor Berdasarkan Komposisi dan Karakteristik Sampah Perkotaan di Indonesia dalam Konsep Waste to Energy. Jurnal Teknik Lingkungan. 2010;16(2):103-14.

[32] Winahyu D, Hartoyo S, Syaukat Y. Strategi Pengelolaan Sampah pada Tempat Pembuangan Akhir Bantargebang, Bekasi. Jurnal Manajemen Pembangunan Daerah. 2013;5(2).

[33] Octavianthy D, Purwanto WW. Designing smart energy system for smart city through municipal solid waste to electricity: techno-economic analysis. InE3S Web of Conferences 2018(Vol. 67, p. 02044). EDP Sciences. 